\title{
Clinical Study of Severe Influenza Virus Pneumonia That Caused Acute Respiratory Failure
}

\author{
TOMOTAKA KAWAYAMA*,**, REI FUJIKI*,**, TORU RIKIMARU** \\ AND KOTARO OIZUMI** \\ *Division of Respiratory Medicine, Social Insurance Tagawa Hospital, Tagawa 826-8585 \\ and ${ }^{* *}$ Department of Medicine, Kurume University School of Medicine, \\ Kurume 830-0011, Japan
}

\begin{abstract}
Summary: The mortality of the influenza virus pneumonia is on the increase caused by the decline of the vaccination for the influenza virus in Japan. The purpose of our research is to study the clinical feature of severe influenza virus pneumonia that caused acute respiratory failure. This study included 68 patients with adult influenza virus infection who consulted our hospital between October 1997 and May 1999. Six (8.8\%) of 68 were diagnosed as having influenza virus pneumonia that caused acute respiratory failure. All patients with influenza virus pneumonia showed severe conditions with respiratory failure and a high-risk group. Two super high age patients had emergency status with unconsciousness. A super high age patient with influenza virus pneumonia died of aspiration pneumonia 118 days after admission. All patients with influenza virus pneumonia were received antibiotics. Although 4 of 6 patients did not respond to antibiotics, adrenocorticosteroids were administered. As the result, 3 of 4 patients, healing was achieved. We concluded that adrenocorticosteroids might be useful for treating severe influenza virus pneumonia under the administration of appropriate antibiotics.
\end{abstract}

Key words influenza virus, pneumonia, respiratory failure

\section{INTRODUCTION}

Influenza virus pneumonia is an important complication that influences the patient's prognosis. During the epidemics, it is generally known that pneumonia often follows a poor prognosis especially in the highrisk group consisting of elderly patients and those with underlying diseases [1-4]. In the United States, it is estimated that mortality increases by 20,000 or 30,000 persons during the influenza virus prevalence period, and that elderly patients comprise approximately $80 \%$ of the mortality [5]. Therefore, the treatment and prevention of pneumonia may be an important issue. Recent studies have reported the usefulness of amantadine hydrochloride and ribavirin for influenza virus type A infection as well as the usefulness of neuraminidase inhibitors for influenza virus type A and/or B infection [6-10]. However, it has not been demonstrated that these agents are useful for treating and preventing severe influenza virus pneumonia. Furthermore, influenza virus pneumonia is classified into 3 types: primary viral pneumonia; secondary bacterial pneumonia following viral infection; and mixed pneumonia in which both types of pneumonia concurrently develop. Previously, many studies have examined influenza virus pneumonia using experimental infection models. The pathogenesis of influenza virus pneumonia has gradually been clarified [11-14]. However, few clinical studies have examined the details of human influenza virus pneumonia. Many respects remain to be clarified. We conducted this study to clarify the clinical features of severe influenza virus pneumonia that caused acute respiratory failure and establish an appropriate treatment. 


\section{MATERIALS AND METHODS}

\section{Patients}

This study included 68 patients with adult influenza virus infection who consulted the Division of Respiratory Medicine, Social Insurance Tagawa Hospital between October 1997 and May 1999.

\section{Diagnosis of influenza virus pneumonia}

Adult influenza virus infection was diagnosed by culture from nasopharyngeal swab or serological test using paired sera. If influenza virus was isolated from nasopharyngeal swab, that specimen was considered to be a definitive pathogen. Serum samples were tested by hemagglutination test or complement fixation test (Mitsubishi Bio. Chem. Lab., Japan). Patients with fourfold or more differences between acute-phase serum antibody titer and convalescentphase serum antibody titer were regarded as having this infection. Patients with high serum antibody titers at one point were excluded.

Criteria for pneumonia included (1) fever of 38 degrees or higher, (2) respiratory symptoms such as cough, sputum, and dyspnea, (3) abnormal respiratory sounds such as coarse crackle, (4) positive inflammation findings such as the peripheral blood leukocyte count, erythrocyte sedimentation rate, and serum $C$ reactive protein $(\mathrm{CRP})$ level $(>0.7 \mathrm{mg} / \mathrm{dl})$, and (5) the presence of abnormal shadows on chest radiograph and thoracic computed tomography (CT). Patients who met 3 items or more including item No. (5) were diagnosed as having pneumonia. However, lesions other than infection, such as congestive heart failure, eosinophilic pneumonia, pulmonary infiltration of malignant disease, or pulmonary lesions related to acquired immunodeficiency syndrome, were excluded. Because we purpose to investigate clinical features of primary influenza virus pneumonia, patients with definitive secondary influenza pneumonia were excluded. Secondary influenza pneumonia defined as new infiltrates of the chest revealed by radiographic examination after 7 days from the initial illness.

\section{Microbiological studies for mixed influenza virus pneumonia}

Multiple pathogens in patients with influenza virus pneumonia were examined as follows.

When bacteria were isolated from blood culture, the bacteria were considered to be definitive causative pathogen. Bacteria, fungus, and acid-fast bacilli were cultured from sputum, pharyngeal swab, and bronchial lavage fluid. Bacteria showing heavy growth ( $\geq 10^{7}$ colony-forming units $/ \mathrm{ml}$ ) of a predominant sputum culture was considered to be causative pathogen. If fungus was detected from specimens and plasma $(1 \rightarrow 3)$ - $\beta$-D-glucan levels were high $(>20 \mathrm{pg} / \mathrm{ml})$, that specimen was considered to be a definitive pathogen. If mycobacterium was detected from specimens, that specimen was considered to be a definitive pathogen if the culture showed little growth. Serological examinations for adenovirus (complement fixation test), Mycoplasma pneumoniae (complement fixation test), Chlamydia spp. (enzyme-linked immunosorbent assay), or Legionella spp. (indirect fluorescence assay) infections were performed using paired sera (Mitsubishi Bio. Chem. Lab., Japan). For serological examinations, a fourfold increase in the antibody titer level between paired sera was considered definitive.

\section{Design of clinical studies}

Age, gender, underlying disease, and history of influenza virus vaccination were compared between the influenza virus pneumonia group and the group with conditions other than pneumonia. In addition, in the pneumonia group, patient backgrounds, clinical symptoms, laboratory data, imaging findings, complications, treatment, and prognosis were retrospectively examined based on medical records. Variables were compared using the Fisher's exact test or unpaired $\mathrm{T}$ test. The severity of pneumonia followed the guidelines of community-acquired pneumonia by American Thoracic Society in 1993 [15].

\section{RESULTS}

\section{Patients characteristics}

Of 68 patients with adult influenza virus infection, 59 patients had influenza virus type A infection, while 9 patients had influenza virus type B infection. Ten $(14.7 \%)$ of these 68 patients were diagnosed as having pneumonia. In 4 (5.9\%) of these patients, pneumonia was not diagnosed on the initial consultation, but secondary bacterial pneumonia developed during the course. The remaining 6 patients $(8.8 \%)$ were diagnosed as having influenza virus pneumonia. In all patients with influenza virus pneumonia, influenza virus type A was detected. None of the patients showed influenza virus type B. Furthermore, none of the patients showed concurrent development of infection with other viruses or Mycoplasma, 
Chlamydia, bacterial, or fungal infection.

When the influenza virus pneumonia group was compared to the group with influenza virus infection other than pneumonia, influenza virus pneumonia more frequently developed in males. The incidence was relatively higher in elderly people. The percentage of patients with underlying diseases was higher in the influenza virus pneumonia group. In the two groups, none of the patients received an inoculation of influenza virus vaccine before prevalence (Table $1)$.

Clinical studies of patients with influenza virus pneumonia
Profiles of 6 patients with influenza virus pneumonia were shown in Table 2. Pneumonia developed between December and January. This period was consistent with the influenza virus prevalence period. Patient ages ranged from 44 to 89 years, with a mean of 70.2 years. There were 5 males and 1 female. Five patients had underlying diseases: hypertension with cardiac disease in 2 patients; old pulmonary tuberculosis in 1 patient; chronic pancreatitis in 1 patient; and rheumatoid arthritis-related pulmonary fibrosis and diabetes mellitus in 1 patient.

As the clinical symptoms of influenza virus pneumonia, all patients developed fever and dyspnea. There were few symptoms commonly observed in

TABLE 1.

Profiles of patients with influenza virus infections

\begin{tabular}{|c|c|c|c|c|}
\hline $\begin{array}{l}\text { Influenza virus } \\
\text { infections } \\
\text { (initial diagnosis) }\end{array}$ & $\begin{array}{c}\text { URI* } \\
\text { Bronchitis ** } \\
\text { Asthma }{ }^{* *} \\
n=62\end{array}$ & $\begin{array}{l}\text { Viral pneumonia } \\
\qquad n=6\end{array}$ & p-value & test \\
\hline Influenzavirus type $\mathrm{A} / \mathrm{B}$, & $53 / 9$ & $6 / 0$ & N.S. & fisher's exact \\
\hline Mean age, yr. \pm SD & $56.0 \pm 20.8$ & $70.2 \pm 15.5$ & N.S. & unpaired T \\
\hline Sex, male/female & $20 / 42$ & $5 / 1$ & $\mathrm{P}<0.05$ & fisher's exact \\
\hline Underlying diseases, yes (\%) & $41(66.1)$ & $5(83.3)$ & N.S. & fisher's exact \\
\hline Vaccination, yes $(\%)$ & $0(0)$ & $0(0)$ & N.S. & fisher's exact \\
\hline
\end{tabular}

* URI: upper respiratory tract infection syndrome, $n=23,{ }^{* *}$ acute bronchitis, $n=22$ ( 3 patients with secondary bacterial pneumonia), ${ }^{* * *}$ asthma: bronchial asthma with lower respiratory tract infection, $\mathrm{n}=17$ (a patient with secondary bacterial pneumonia)

TABLE 2.

Characteristics of patients with influenzal pneumonia

\begin{tabular}{|c|c|c|c|c|c|c|}
\hline Patient No. & Age/Sex & Underlying diseases & $\begin{array}{l}\text { Temperature } \\
\text { on } \\
\text { admission, } \\
{ }^{\circ} \mathrm{C}\end{array}$ & Initial symptoms & $\begin{array}{c}\text { Duration of } \\
\text { dyspnea from } \\
\text { initial symptoms, } \\
\text { day }\end{array}$ & Complications \\
\hline 1 & $66 / \mathrm{M}$ & $\begin{array}{l}\text { hypertension, effort } \\
\text { angina }\end{array}$ & 38.1 & $\begin{array}{l}\text { nasal discharge, } \\
\text { headache, cough, } \\
\text { sputa }\end{array}$ & 5 & $\begin{array}{l}\text { disseminated } \\
\text { intravascular } \\
\text { coagulation }\end{array}$ \\
\hline 2 & $76 / \mathrm{M}$ & hypertension & 37.4 & $\begin{array}{l}\text { nasal discharge, } \\
\text { cough }\end{array}$ & 5 & - \\
\hline 3 & $89 / \mathrm{M}$ & - & 39.1 & unconsciousness & 1 & $\begin{array}{l}\text { liver function } \\
\text { disorder }\end{array}$ \\
\hline 4 & $80 / \mathrm{M}$ & $\begin{array}{l}\text { old pulmonary } \\
\text { tuberculosis }\end{array}$ & 39.3 & unconsciousness & 1 & $\begin{array}{l}\text { disseminated } \\
\text { intravascular } \\
\text { coagulation }\end{array}$ \\
\hline 5 & $44 / \mathrm{F}$ & chronic pancreatitis & 38.2 & cough, sputa & 3 & - \\
\hline 6 & $66 / \mathrm{M}$ & $\begin{array}{l}\text { rheumatic lung, } \\
\text { diabetes mellitus }\end{array}$ & 37.1 & $\begin{array}{l}\text { appetite loss, } \\
\text { general fatigue }\end{array}$ & 6 & $\begin{array}{l}\text { liver function } \\
\text { disorder }\end{array}$ \\
\hline
\end{tabular}


TABLE 3.

Laboratory data, findings of roentgenograms, treatment and prognosis in patients with influenzal pneumonia

\begin{tabular}{|c|c|c|c|c|c|c|c|c|c|}
\hline $\begin{array}{l}\text { Patient } \\
\text { No. }\end{array}$ & $\begin{array}{l}\text { white- } \\
\text { cell } \\
\text { counts } \\
/ \mathrm{mm}^{3}\end{array}$ & $\begin{array}{c}\text { Serum levels } \\
\text { of } \\
\text { lactase } \\
\text { dehydrogenase } \\
\text { IU/L }\end{array}$ & $\begin{array}{c}\text { Partial } \\
\text { pressure of } \\
\text { oxygen } \\
\left(\mathrm{FIO}_{2} 21 \%\right) \\
\quad \text { torr }\end{array}$ & $\begin{array}{c}\text { C-reactive } \\
\text { protein } \\
\mathrm{mg} / \mathrm{ml}\end{array}$ & $\begin{array}{l}\text { Findings of } \\
\text { roentgenograms }\end{array}$ & Antibiotics & $\begin{array}{l}\text { adreno- } \\
\text { cortico- } \\
\text { steroid }\end{array}$ & $\begin{array}{l}\text { Amantadine } \\
\text { or } \\
\text { rimantadine } \\
\text { or } \\
\text { neuraminidase } \\
\text { inhibitor }\end{array}$ & prognosis \\
\hline 1 & 4,100 & 476 & 46.0 & 27.9 & $\begin{array}{l}\text { infiltrations with air- } \\
\text { bronchogram in } \\
\text { bilateral lung filds }\end{array}$ & $\begin{array}{l}\text { cefpirom plus } \\
\text { clarithromycin }\end{array}$ & - & - & alive \\
\hline 2 & 11,280 & 498 & 53.6 & 42.9 & $\begin{array}{l}\text { infiltrations with air- } \\
\text { bronchogram in } \\
\text { bilateral lung filds }\end{array}$ & $\begin{array}{l}\text { subactam } \\
\text { /cefoperazone plus } \\
\text { clindamycin }\end{array}$ & - & - & alive \\
\hline 3 & 7,200 & 698 & 48.1 & 21.5 & $\begin{array}{l}\text { diffuse small nodules } \\
\text { reticular shadows }\end{array}$ & $\begin{array}{l}\text { imipenem plus } \\
\text { clarithromycin }\end{array}$ & $\begin{array}{l}\text { m-PSL } 1 \mathrm{~g} / \mathrm{day}, \\
3 \text { days }\end{array}$ & - & death \\
\hline 4 & 4,900 & 595 & 65.8 & 10.5 & $\begin{array}{l}\text { diffuse small nodules } \\
\text { reticular shadows }\end{array}$ & $\begin{array}{l}\text { imipenem plus } \\
\text { amikacin }\end{array}$ & $\begin{array}{l}\text { PSL } 20 \mathrm{mg} / \text { day, } \\
5 \text { days }\end{array}$ & - & alive \\
\hline 5 & 6,820 & 396 & 63.7 & 3.9 & $\begin{array}{l}\text { diffuse small nodules } \\
\text { reticular shadows }\end{array}$ & clarithromycin & $\begin{array}{l}\mathrm{m}-\mathrm{PSL} \\
125 \mathrm{mg} / \text { day, } \\
2 \text { days and PSL } \\
20 \mathrm{mg} / \text { day, } 5 \text { days }\end{array}$ & S & alive \\
\hline 6 & 15,710 & 895 & 53.4 & 16.7 & $\begin{array}{l}\text { diffuse small nodules } \\
\text { reticular shadows }\end{array}$ & imipenem & $\begin{array}{l}\text { m-PSL } 1 \mathrm{~g} / \text { day, } \\
3 \text { days }\end{array}$ & - & alive \\
\hline
\end{tabular}

* m-PSL: methylprednisolone; PSL: prednisolone

(a)

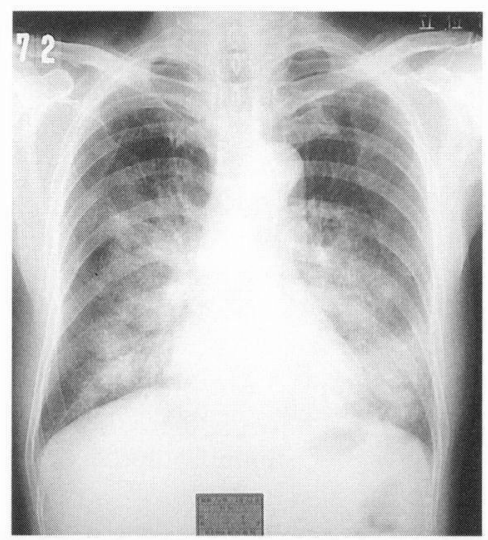

(b)

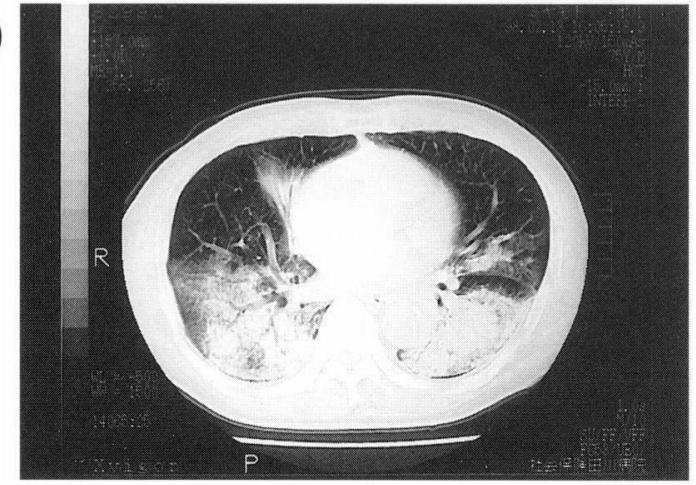

Fig. 1. Chest radiograph (a) and chest computed radiograph (b) taken at the time of admission, showing bilateral pulmonary infiltrates with air-bronchograms. (patient 1) (a)

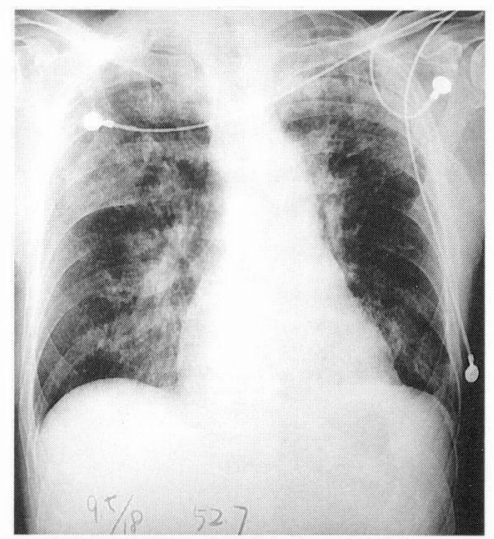

(b)

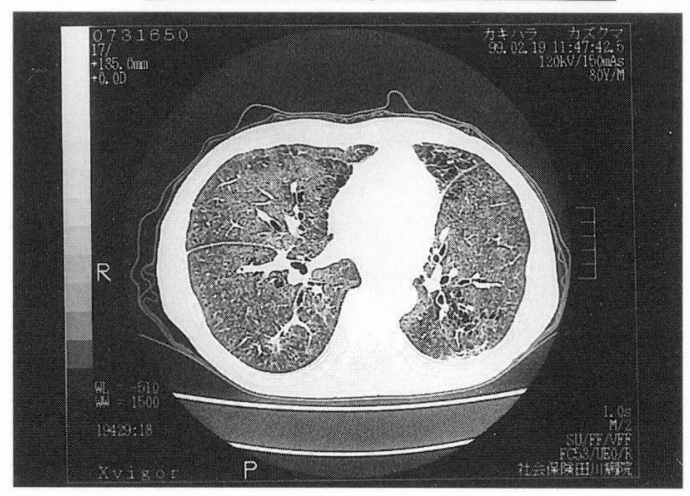

Fig. 2. Chest radiograph (a) and chest computed radiograph (b) taken at the time of admission, showing diffuse small nodular and reticular infiltrates in bilateral lung fields. (patient 4) 
patients with influenza virus infection, such as chill, arthralgia, or lumbar pain. Three of 6 patients consulted our hospital for acute respiratory symptoms. In 2 patients 80 and 89 years old respectively, lacked respiratory symptoms. These patients were emergency admitted for consciousness disorder. In all patients, the interval between the initial symptoms of infection and dyspnea was 7 days or less.

As complications, disseminated intravascular coagulation syndrome and liver dysfunction were observed in 2 patients each (Table 2).

\section{Laboratory data and prognosis in patients with influenza virus pneumonia}

Laboratory data, imaging findings, treatment, and prognosis are shown in Table 3.

With respect to laboratory data, all patients showed marked hypoxemia. In some patients, CRP levels were increased. Peripheral blood leukocytosis was observed in 2 of 6 patients. The high levels of serum lactate dehydrogenase were noted in 5 of 6 patients.

Chest radiograph and CT revealed multiple infiltrates with air-bronchogram involving bilateral lung fields in 2 patients (Patients 1 and 2) and diffuse small nodular and reticular infiltrates in 4 patients (Patients 3-6). In the former group (Fig. 1a, b), administration of antibiotics including beta-lactams resulted in healing. However, in the latter group (Fig. $2 a, b)$, the patients did not respond to antimicrobials. Therefore, adrenocorticosteroids including methylprednisolone were administered after three to four days from the treatment of antibiotics. As the result, in 3 of 4 patients, healing was achieved. In the remaining patient (Patient 3), improvement was transiently achieved by administration of an adrenocorticosteroid. However, the patient became bedridden thereafter, and died of aspiration pneumonia 118 days after admission.

In this study, none of the patients received any anti-influenza virus agents, amantadine hydrochloride, ribavirin, or neuraminidase inhibitors.

\section{DISCUSSION}

Influenza virus pneumonia is observed in about 30 to $40 \%$ of patients with influenza virus infection, and is an important complication [1-4]. However, few studies have reported the clinically incidence of primary influenza virus pneumonia.

In this study, influenza virus pneumonia was detected in approximately $8.6 \%$ of patients with influenza virus infection. All patients were infected with influenza virus type $A$. The time of onset was consistent with the influenza virus prevalence period. Furthermore, the incidence of influenza virus pneumonia was high in the high-risk group consisting of elderly patients with underlying diseases. The incidence of influenza virus infection was higher in females. However, the incidence of influenza virus pneumonia was higher in males. Concerning clinical symptoms, in patients with influenza virus pneumonia, chill, systemic muscle pain, lumbar pain, and acute upper airway inflammation, which are specific to influenza virus infection, were not frequently observed. In contrast, anorexia, general malaise, and consciousness disorder were frequently observed. This may have been because most patients were of advanced age.

It has been reported that influenza virus infiltrates the bronchus and bronchiole via the airway, causing exfoliation, drop, and degenerative necrosis of the bronchial or bronchiolar epithelium $[11,12]$. Therefore, secondary bacterial infection may easily occur after influenza virus infection [16]. In other words, influenza virus pneumonia is classified into 3 types: pneumonia caused by virus-related direct pulmonary injury; bacterial pneumonia following influenza virus infection; and mixed pneumonia in which both types of pneumonia concurrently develop. In this study, patients with secondary pneumonia were excluded, and it was necessary to differentiate primary pneumonia from mixed pneumonia. It was difficult to differentiate the two types based on clinical symptoms and laboratory data.

Generally, many patients with viral pneumonia show shadows scattered via the airway and viremiarelated pulmonary lesions, that is, pulmonary parenchymal and interstitial injury. Viral pneumonia has been reported to show various imaging findings compared to bacterial pneumonia [16-18]. In this study, imaging findings were classified into infiltrates with air-bronchogram and diffuse small nodular and reticular infiltrates. Patients 1 and 2 showed infiltrates with air-bronchogram on chest radiograph. Although causative bacteria were not identified, antibiotics were effective. We might be suggested that Patients 1 and 2 defined as mixed pneumonia involving bacterial infection. We considered that diffuse small nodular and reticular infiltrates (Patients 3-6), which should be differentiated from summer type hypersensitivity pneumonitis in Japan, were associated with primary influenza virus pneumonia. Although the number of patients was small, imaging 
findings including CT findings may be useful for differentiating primary pneumonia from mixed pneumonia, and may be very important for treatment.

Amantadine hydrochloride and ribavirin have been reported to be useful for treating influenza virus type A infection [6-8]. However, few studies have reported the usefulness of these agents in the treatment of severe influenza virus type A infection. In recent years, the appearance of amantadine hydrochloride-resistant strains has been indicated. Caution is needed in prescribing this agent $[20,21]$. Embrey et al. [22] reported that patients with severe influenza virus type A pneumonia who developed acute respiratory failure during administration of immunosuppressive agents responded to combination therapy with amantadine hydrochloride and ribavirin. The usefulness of each agent alone or combination of two agents for severe influenza virus infection should be examined in the future. Recently, neuraminidase inhibitors have been expected to be useful for treating and preventing influenza virus type A or type B infection $[9,10]$. However, neuraminidase inhibitors show slight therapeutic and prophylactic effects in healthy adults. None of the previous studies have reported the treatment responses of elderly patients or severe cases. The usefulness of these inhibitors has not been still clearly demonstrated.

Briefly, treatment for severe influenza virus infection has not yet been established. In our series, to treat viral pneumonia, adrenocorticosteroids were administered under administration of antibiotics. Three of 4 patients responded to this treatment. The remaining patient transiently responded to an adrenocorticosteroid, although the patient finally died. Although short course administration of adrenocorticosteroids did not cause any serious side effects, treatment with adrenocorticosteroids for respiratory infection remains controversial. But it is recommended that aggressive administration should be avoided [23-25]. Dakhama et al. [26] performed polymerase chain reaction, and reported that influenza virus type A DNA was detected in 6 of 13 samples of bronchoalveolar lavage fluid collected from patients with hypersensitivity pneumonitis. They indicated that influenza virus type A may be involved in allergic reaction in which the virus itself or viral components act as an antigen other than infection-related direct injury of the airway [27]. This may be a reason why adrenocorticosteroids were effective in 4 patients with primary pneumonia demonstrating hypersensitivity pneumonitis-like images in our study.

In our study, influenza virus pneumonia was severe in most patients. These patients were of advanced age, and had underlying diseases, and comprised a high-risk group. One of 6 patients died of influenza virus infection. In the United States, the rate of influenza virus vaccination for high-risk groups, including elderly people has rapidly increased. In 1996, the rate of vaccination in elderly people was 65\% [5]. However, in Japan, the rate of vaccination has slightly decreased year by year [28]. Since a marked prevalence in 1998/1999, an interest in vaccination has improved. However, in our area, the rate of vaccination is approximately $5 \%$. In this study, the rate was $0 \%$. Currently, there are few effective anti-influenza virus agents, and the importance of vaccination should be reviewed.

\section{REFERENCES}

1. Simonsen L, Clarke MJ, Williamson GD, Stoup DF, Arden NH et al. The impact of influenza epidemics on mortality: Introducing a severity index. Am J Public Health 1997; 87:1944-1950.

2. Barker WH. Excess pneumonia and influenza associated hospitalization during influenza epidemics in the United States, 1970-78. Am J Public Health 1986; 76:761-765.

3. Glezen WP. Serious morbidity and mortality associated with influenza epidemics. Epidemiol Rev 1982; 4:25-44.

4. Kashiwagi S, Ikematsu H, Hayashi J, Nomura H, Kajiyama W et al. An outbreak of influenza A (H3N2) in a hospital for the elderly with emphasis on pulmonary complications. Jpn J Med 1988; 27:177-182.

5. Perrotta DM, Decker M, and Glezen WP. Acute respiratory disease hospitalizations as a measure of impact of epidemic influenza. Am J Epidemiol 1985; 122:468-476.

6. Monto AS, Gunn RA, Bandyk MG, and King CL. Prevention of Russian influenza by amantadine. JAMA 1979; 241:1003-1007.

7. Tominack RL, and Hadyden FG. Rimantadine hydrochloride and amantadine hydrochloride use in influenza A virus infections. Infect Dis Clin North Am 1987; 1:459-478.

8. Sidwell RW, Bailey KW, Wong MH, and Huffman JH. In vitro and in vivo sensitivity of a non-mouse-adapted influenza A (Beijing) virus infection to amantadine and ribavirin. Chemotherapy 1995; 41:455-461.

9. Hayden FG, Osterhans ADME, Treanor JJ, Fleming DM, Aoki FY et al. Efficacy and safety of the neuraminidase inhibitor zanamivir in the treatment influenzavirus infections. N Engl J Med 1997; 337:874-880.

10. Monto AS, Robinson DP, Herlocher ML, Minson JM Jr, Elliott MJ et al. Zanamivir in the prevention of influenza among healthy adults. A randomized controlled trial. JAMA 1999; 282:31-35.

11. Hers JF, Mulder J, Masurel N, Kuip L, and Tyrrell DAJ. 
Studies on the pathogenesis of influenza virus pneumonia in mice. J Path Bact 1962; 83:207-217.

12. Scott GH, and Sydiskis RJ. Responses of mice immunized with influenza virus by aerosol and parenteral routes. Infect Immun 1976; 13:696-703.

13. Peschke T, Bender A, Nain M, and Gemsa D. Role of macrophage cytokines in influenza A virus infection. Immunobiol 1993; 189:340-355.

14. Karupiah G, Chen JH, Mahalingam S, Nathan CF, and MacMicking JD. Rapid interferon - dependent clearance of influenza A virus and protection from consolidating pneumonitis in nitric oxide synthase 2-deficient mice. J Exp Med 1998; 188:1541-1546.

15. Niederman MS, Bass JB Jr., Campbell GD, Fein AM, Grossman RF et al. Guidelines for the initial management of adult with community-acquired pneumonia: Diagnosis, assessment of severity, and initial antimicrobial therapy. Am Rev Resir Dis 1993; 148:1418-1426.

16. Ramphal R, Small PM, Shands JW, Fischlschweiger W, and Small PA Jr. Adherence of Pseudomonas aeruginosa to tracheal cells injured by influenza infection or by endotracheal intubation. Infect Immun 1980; 27:614-618.

17. Gremillion DH, and Crawford GE. Measles pneumonia in young adults. An analysis of 106 cases. Am J Med 1981; 71:539-542.

18. Ramsey PG, Fife KH, Hackman RC, Meyers JD, and Corey L. Herpes simplex virus pneumonia, clinical, virologic, and pathologic features in 20 patients. Ann Intern Med 1982; 97:813-820.

19. Conti JA, and Karetzky MS. Varicella pneumonia in the adult. N Eng J Med 1989; 86:475-478.
20. Oxford JS, Logan IS, and Potter CW. In vivo selection of an influenza A2 strain resistant to amantadine. Nature 1970; 226:82-83.

21. Hayden FG, and Hay AJ. Emergence and transmission of influenza A viruses resistant to amantadine and rimantadine. Curr Top Microbiol Immunol 1992; 176:119-130.

22. Embrey RP, and Geist LJ. Influenza A pneumonitis following treatment of acute cardiac allograft rejection with murine monoclonal anti-CD3 antibody (OKT3). Chest 1995; 108:1456-1459.

23. Monterar JSG, Russell JA, Lawson L, and Ruedy J. Acute respiratory failure secondary to Pneumocystis carinii pneumonia in the acquired immunodeficiency syndrome: a potential role for systemic corticosteroids. Chest 1989; 95:881-884.

24. Bone RC, Fisher CJ, Clemmer TP, Slotman GJ, Metz CA et al. Early methylprednisolone treatment for septic and the adult respiratory distress syndrome. Chest 1987; 92:1032-1037.

25. Senderovitz T, and Viskum K. Corticosteroid and tuberculosis. Respir Med 1994; 88:561-565.

26. Dakhama A, Hegele RG, Laflamme G, Israel-Assayag E, and Cormier Y. Common respiratory viruses in lower airways of patients with acute hypersensitivity pneumonitis. Am J Respir Crit Care Med 1999; 159:13161322.

27. Leung KN, and Ada GL. Cell mediation delayed-type hypersensitivity in the lung of mice infected with an influenza A virus. Scnd J Immunol 1980; 12:393-400.

28. Hirota Y, Fedsom DS, and Masao K. Japan lagging in influenza jobs. Nature 1996; 380:18. 